Красинский Владислав Вячеславович

доктор юридических наук, член Общественного

консультативного научно-методического Совета

при ЦИК России

Красинский B.B. Салафитско-ваххабитский фактор и его использование в общественнополитической жизни Северо-кавказского региона // Гражданин. Выборы. Власть. 2013. № 2.

\title{
Салафитско-ваххабитский фактор и его использование в общественно- политической жизни Северо-кавказского региона
}

В настоящее время общественно-политическая обстановка на территории Северного Кавказа остается сложной. Существенное влияние на нее оказывают:

- низкий жизненный уровень и массовая безработица среди местного населения, отсутствие перспектив для молодых специалистов; управления;

- высокий уровень коррупции в органах государственной власти и

- неразрешенные межэтнические конфликты и территориальные споры (осетино-ингушский конфликт с очагом напряженности в Пригородном районе Северной Осетии, территориальные споры между чеченцамиакинцами, лакцами, аварцами и кумыками в Казбековском и Новолакском районах Республики Дагестан, спор между кабардинцами и балкарцами об отгонных пастбищах и др.);

- «арабизация» Северо-кавказского региона (далее-СКР), используемая салафитскими (ваххабитскими) идеологами для пропаганды джихада и перехода к шариатскому правлению;

- террористическая активность бандподполья под прикрытием псевдоисламской атрибутики и догматики.

В условиях общегосударственного идеологического вакуума все более значительную роль в общественно-политической жизни региона играет ислам. Стремительность возрождения ислама можно видеть по росту числа мечетей (их число выросло более чем в 100 раз с 1980 г.) ${ }^{1}$, поддержке государством исламского образования, по количеству паломников, ежегодно совершающих хадж в Мекку.

Традиционно исламскими являются этнические группы аварцев, адыгейцев, балкарцев, даргинцев, ингушей, чеченцев, кабардинцев, карачаевцев, кумыков, лакцев, лезгинов и др. В Карачаево-Черкесии, Ставропольском крае и Северной Осетии значительную часть населения

1 Северный Кавказ: сложности интеграции. I. Этничность и конфликт. Доклад Международной кризисной группы.

URL: http://www.polit.ru/article/2012/11/30/Ethnicity_and_Conflict/ (дата обращения: 04.01.2013). 
составляют христиане. Большинство мусульманского населения СКР придерживается ханафитского и шафиитского мазхабов суннитской ветви ислама. В Чечне, Ингушетии и Дагестане широко распространен суфизм кадирийского, накшбандийского и шазилийского толков.

В республиках Северного Кавказа ислам используется как ядро политической идеологии, региональной идентичности, этнического самосознания. Возрождение в рамках исламских ценностей стало частью политической культуры многих народов Северного Кавказа, частью их психологии и образа жизни ${ }^{2}$.

Активные попытки спекуляции идеями исламского возрождения предпринимают сторонники джихадистского салафизма (от араб. «салаф» предки) (ваххабизма) ${ }^{3}$. Эти фундаменталистские течения объединяет призыв к очищению религии и возврату к истокам, к эпохе пророка Мухаммеда и четырех «праведных халифов» («аль-хулафа аль-рашидун»), а также признание Корана и Сунны единственным источником права.

Главной идеей данных течений является отрицание любых нововведений в области вероучения («бид'а»), не обоснованных в Коране и хадисах, «очищение ислама» от адатов (чтение Корана на могилах, подношения мечетям, мавлид, обрядовая практика суфиев и др.).

В общественно-политической сфере фундаменталисты проповедуют социальное равенство, братство и единство всех мусульман, строгое соблюдение морально-этических принципов ислама. Политической целью выступает замена светских («безбожных», «кафирских») органов публичной власти властью Аллаха и создание справедливого государства с шариатской формой правления. При этом отвергается верховенство Конституции Российской Федерации, ценность институтов народного представительства и конституционно-правовых процедур их формирования.

Носители салафитско-ваххабитских идей имеют нигилистическое правосознание, подвергают сомнению демократический путь разрешения противоречий в обществе и необходимость участия в политической жизни.

2 Дадуев М., Нунуев С.-Х. Этнический и религиозный экстремизм как угроза национальной безопасности в постсоветском пространстве (на материалах Северного Кавказа) // Россия и мусульманский мир: научно-информационный бюллетень / РАН ИНИОН. М., 2013. № 4 (250). С. 43.

3 Салафийя, или салафизм - идеи очищения ислама и восстановления религии «праведных предков» (салафов), т.е. праведных мусульман времен Пророка Мухаммеда и последующих двух поколений. Следующие поколения после салафов именуют халафами. Можно выделить три этапа салафизма: 1) возникновение салафитского движения в 4/9 веке (по хиджре/по григ. к) среди ученых ханбалитского мазхаба; 2) развитие салафизма в 7/12 веке в работах сирийского ученого Така ад-Дин Ибн Таймийи; 3) возрождение салафизма в 18 веке Мухаммедом ибн Абд аль-Ваххабом, ставленником британской разведки, с целью борьбы с Османской империей путем внесения раскола в ислам и последующей дискредитации мусульманской религии. В теории различают несколько основных классификаций салафизма: джихадистский-неджихадистский, консервативныйреформаторский и др. Подробней см. В.В. Наумкин. Исламский радикализм в зеркале новых концепций и подходов. М.: КомКнига, 2005. С. 455; М. Абу Захра. История течений в исламе. Каир, 1996. с.194; Признания английского шпиона. Махачкала, 2008. 104 с.; Где Ирак, а где Неджд или с чего начинался ваххабизм? Отдел исламского просвещения. Махачкала.: ДУМД, 2008. 53 с. 
В религиозной сфере приверженцы салафизма (ваххабизма) отрицают посредничество между мусульманами и Аллахом («тавассуль»): отвергают поклонение Пророку, любимцам Аллаха («авлия»), праведникам, а также святым местам (зияратам, мавзолеям, мазарам, могиле Пророка, камням АльХаджар аль-асвад, Макам Ибрахим и др.) («зиярат аль-кубур»)4.

Современными салафитско-ваххабитскими группировками отрицается необходимость следования классическим суннитским мазхабам, изучения фикха (юриспруденции $)^{5}$. Провозглашается буквальное толкование Корана и хадисов (таклид) ${ }^{6}$.

Салафитское течение присутствовало в Северо-кавказском регионе еще до распада Советского Союза, но за последнее десятилетие часть его приверженцев радикализовалась, приобрела боевой опыт и включилась в борьбу против государства с целью создания исламского халифата.

В настоящее время отмечается тенденция сближения салафизма и ваххабизма в СКР. После двух чеченских кампаний и вооруженного вторжения Исламской Армии Кавказа во главе с М. Багауддином, Ш. Басаевым и Хаттабом в Республику Дагестан в 1999 г. в общественном сознании понятие «ваххабизм» приобрело негативный оттенок. Поэтому приверженцы ваххабитских взглядов в стремлении завоевать доверие мусульман Северного Кавказа скрывают свою идейную принадлежность и прикрываются наименованиями «салафиюны», «салафиты», «единобожники», «ихваны» 7.

Несмотря на эти ухищрения и псевдоисламскую мимикрию, экстремистская сущность салафистско-ваххабитских идей на территории Северного Кавказа заключается в их направленности на:

4 См. Ахмад бин Зайни Дахлян. Ваххабизм, какой он есть (Величественные жемчужины в отпор ваххабизму). Махачкала.: ДУМД, 2008. С. 40, 42, 84; Где Ирак, а где Неджд или с чего начинался ваххабизм? Отдел исламского просвещения. Махачкала: ДУМД, 2008. С. 17, 18. Аль-Хаджар аль-асвад - черный камень в углу Каабы; Макам Ибрахим - камень, на котором во время постройки Каабы стоял пророк Ибрахим.

5 Первоначально источником становления и развития ваххабитских идей был ханбалитский мазхаб, основанный ученым-богословом Ахмадом ибн Ханбалом (ум. в 241 г. по хиджре, 855 г.по григ. к.). Основатель ваххабизма - шейх Мухаммед ибн Абд альВаххаб (ум. 1206 г. по хиджре (1791 г. по григ. к.) утверждал, что он придерживается мазхаба имама Ахмада и называл свои убеждения термином «салафийя». Кроме того, в основу учения ибн Абд аль-Ваххаба легли работы сирийского теолога Така ад-Дина ибн Таймии.

${ }^{6}$ Салафиты (ваххабиты) используют удобную для себя интерпретацию Корана. В частности, идеологи этого течения считают не ставших ваххабитами (салафитами) мусульман предателями, которых можно убивать, а их имущество делить между собой. Между тем, в кораническом аяте 5:32 говорится: «Если кто-либо убьет человека не за убийство или распространение нечестия на земле, тот словно убил всех людей, а кто сохранит жизнь человеку, тот словно сохранит жизнь всем людям».

7 По словам муфтия Королевства Саудовская Аравия Аб̆д Аль-Азиз ибн База: «Салафит - это каждый, кто идет по пути наших праведных предков и следует их программе». Саудовское руководство официально обращалось к правительству России с просьбой не использовать термин «ваххабизм» в отношении боевиков в Дагестане. Цит. по Мантаев A.A. «Ваххабизм» и политическая ситуация в Дагестане. Дис. ... канд. полит. наук. М., 2002. С. 16, 76; К.И.Поляков. Арабский Восток и Россия: проблемы исламского фундаментализма. Москва, 2001, с.79. 
- разжигание религиозной розни и дестабилизацию внутриконфессиональной обстановки в мусульманской умме России ${ }^{8}$;

- инспирирование нарушения территориальной целостности Российской Федерации путем создания шариатского государства в форме халифата - «Имарата Кавказ» ${ }^{9}$;

- замену светских («безбожных») органов публичной власти религиозными, вооруженную борьбу с государственными и муниципальными органами;

- публичное оправдание терроризма, основанное на интерпретации джихада как войны с инаковерующими ${ }^{10}$.

Разжигание религиозной розни и попытки дестабилизации внутриконфессиональной обстановки в мусульманской умме России связаны с тем, что салафитско-ваххабитские группировки считают неверными («кафирами») всех несогласных с их трактовкой ислама ${ }^{11}$. Так, салафитсковаххабитские идеологи называют традиционный для Северного Кавказа тарикат (тасаввуф) «путем шайтана», наставников-устазов - «идолами», а их мюридов - «идолопоклонниками». Выступают за слепое следование Корану («таклид») и считают «слабыми» все хадисы Пророка, которые опровергают их убеждения.

Негативное влияние на внутриконфессиональную обстановку в мусульманской умме России оказывает искусственное деление единобожия («таухид») на «таухид рубубийя» (признание язычниками Аллаха единственным Господом) и «таухид улюхийя» (признание Аллаха единственным Богом) $)^{12}$. Коранические аяты о многобожниках и неверных вырываются из контекста и манипулятивно применяются в отношении мусульман.

По мнению приверженцев салафизма (ваххабизма), решающим свидетельством единобожия является абсолютное подчинение салафитсковаххабитской общине и вражда по отношению к инаковерующим («кафирам», «мунафикам», «муртадам», «мушрикам»).

8 Салафиты называют себя салафиюнами («предшествующими алимами»), пропагандируют свою исключительность по признаку религиозной принадлежности (полагают, что только они могут считаться «истинными мусульманами») и обвиняют всех несогласных в неверии (такфир)).

98 февраля 2010 г. Верховный Суд Российской Федерации признал «Имарат Кавказ» террористической организацией. В мае 2011 г. в соответствии с исполнительным указом Президента США № 13224 «Имарат Кавказ» был признан террористической организацией Государственным департаментом США. 29 июля 2011 г. СБ ООН включил «Имарат Кавказ» в список организаций, связанных с «Аль-Каидой».

10 Смирнов B.A. Исламский радикализм: вызов современному миру / Материалы III Всероссийской научно-практической конференции «Концепция противодействия терроризму в Российской Федерации. Комплексный подход к формированию и функционированию системы противодействия распространению идеологии терроризма. М., РГУНГ, 2012. Т.2 С. 134.

11 Распространенные на Кавказе ханафитский и шафиитский мазхабы характеризуются терпимостью к инаковерующим. В кораническом аяте 18:29 закреплена веротерпимость: «Истина - от вашего Господа. Кто хочет, пусть верует, а кто не хочет, пусть не верует».

12 Ахмад бин Зайни Дахлян. Ваххабизм, какой он есть (Величественные жемчужины в отпор ваххабизму). Махачкала.: ДУМД, 2008. С. 88, 91. 
Не случайно информационные ресурсы северо-кавказского бандподполья помимо пропаганды (даваата) салафизма, материалов о лидерах джихада формируют нетерпимость по отношению к России («кафирской Русне»), призывают к «чистому» исламу и джихаду против неверия (куфра) и язычества (ширка), к борьбе против оккупации кафирами исламской территории (дар аль-ислам) ${ }^{13}$.

Псевдоисламские салафистско-ваххабитские

религиозно-

экстремистские идеи не имеют ничего общего с духовным поиском внутри ислама. Напротив, они подрывают гуманную основу ислама веротерпимость и ненасильственный призыв к единобожию ${ }^{14}$. Внедряемое таким путем в массовое сознание салафитско-ваххабитское учение ведет к расколу в мусульманской среде и, в конечном счете, к дискредитации ислама в глазах мировой общественности.

Закрепленные в Конституции Российской Федерации федеративное государственное устройство России (ст. 5 Конституции) и светский характер государства (ст. 14 Конституции) подрываются салафитско-ваххабитской концепцией построения халифата в мусульманских республиках Северокавказского региона.

Современная трактовка экстремистских лозунгов, инспирирующих нарушение территориальной целостности Российской Федерации, возникла в 2007 г. после провозглашения неоднократно судимым Доку Умаровым создания на Северном Кавказе шариатского государства «Имарат Кавказ», в которое вошли вилаяты (области): Чечня, Ингушетия, Дагестан, Объединенный вилаят Кабарды, Балкарии и Карачая, Ногайская степь ${ }^{15}$.

Помимо нагнетания сепаратистских настроений на территории Северного Кавказа, экстремистски настроенные салафиты (ваххабиты) идеологически обосновывают и время от времени в ряде районов осуществляют замену светских институтов публичной власти религиозными. Примером могут служить «кадарская зона» (Кадар, Карамахи, Чабанмахи, Чанкурбе, Губден), села Ново-Саситли, Муцал-аул, Кироваул и ряд др. анклавов на территории Республики Дагестан, фактически изъятых из юрисдикции федеральной власти.

Предыстория становления альтернативной «исламской» государственности в Российской Федерации имеет «чеченские» корни. В сентябре 1996 г. Президент Чеченской Республики Ичкерия 3. Яндарбиев взял курс на исламизацию. В Республике были упразднены светские

13 Такого рода воззвания регулярно размещаются на сайтах Kavkaz-Center.com, Kavkaz.org.uk, Camagat.com, Guraba.info, VDagestan.com, Hunafa.com, Islamdin.biz, Imamtv.com, Nuruddin.info, Nohchipress.info, Daavat.me и др.

i4 Деструктивная антиобщественная направленность салафитско-ваххабитских идей обусловила запрет в Российской Федерации главного труда Мухаммеда ибн абд альВаххаба - «Книги Единобожия» («Китаб-ат-Таухид»). «Книга Единобожия» внесена Министерством юстиции Российской Федерации в федеральный список экстремистских материалов.

15 Идею создания на Кавказе единого исламского государства еще в 1998 г. выдвигал С. Радуев: «У нас одна цель - создание на Кавказе единого исламского государства, куда будут входить Ичкерия, Дагестан, Кабарда, Балкария, Ингушетия, Карачаево-Черкесия, Азербайджан» // Независимая газета. 1998. 3 февраля. 
судебные органы, введен в действие исламский Уголовный кодекс. По всей Чечне начали действовать шариатские суды, в состав которых вошли муджахиды ваххабитских джамаатов и граждане арабских государств. Была создана шариатская гвардия.

Позднее идеология и практика замены конституционных («кафирских», «безбожных») органов публичной власти шариатскими была перенесена на некоторые районы Дагестана.

7 марта 1999 года в Республике Дагестан прошли выборы в Народное Собрание республики. Джамаат «кадарской зоны» блокировал их проведение в населенных пунктах Карамахи, Чабанмахи, Кадар, Чанкурбе и Ванашимахи.

«Там, «наверху», сами заявляют о том, что среди депутатов немало бывших уголовников. А нам вся эта грязь не нужна. Мы - мусульмане - за свои действия отвечаем перед Аллахом в Судный день. Для них важнее деньги и власть. Они забыли Ислам. Или же, где им надо, козыряют именем Ислама. Повторяю, такого лицемерия нам не надо. А если бы мы за них проголосовали, нам бы отвечать перед Аллахом». Так объяснил отказ от голосования военный «амир» карамахинского Джамаата Джарулла.

В ответ на обращение руководства Республики к населению указанных сел карамахинский джамаат направил в Махачкалу документ, в котором, в частности, говорилось: «В связи с тем, что республика не способна своей конституцией, многочисленными законами навести элементарный порядок, в Дагестане следует установить законы Аллаха. Только установив шариатские законы, можно навести порядок, как, например, в селах Карамахи и Чабанмахи» ${ }^{16}$.

Салафитское (ваххабитское) понимание монотеистического принципа таухида неизбежно требует устранения «власти неверных» для установления власти Аллаха и построения исламского государства ${ }^{17}$. В качестве инструмента постепенной замены конституционных «кафирских» органов власти на «шариатские» выступают непрекращающиеся посягательства на жизнь и теракты в отношении депутатов, должностных лиц и сотрудников органов власти и управления, сотрудников правоохранительных структур ${ }^{18}$.

Фанатичный настрой салафитско-ваххабитских апологетов на вооруженную борьбу с государственными и муниципальными органами власти, мусульманским духовенством, публичное оправдание терроризма как «войны с неверными» привели к фактическому состоянию войны между традиционалистским исламом и официальными властями, с одной стороны, и

${ }^{16}$ Мантаев А.А. «Ваххабизм» и политическая ситуация в Дагестане. Дис. ... канд. полит. наук. М., 2002. С. 208.

17 Макаров Д.В. Несостоявшееся возрождение умеренного исламизма в Дагестане. URL: http://www.islamrf.ru/news/umma/islam-world/2585 (дата обращения: 07.05.2013).

${ }_{18}$ Расулов Я. Почему убивают милиционеров в Дагестане // Черновик. 2004. 16 апреля; Курбанов $P$. Расползание джихада: первичные факторы и масштабы радикализации ислама на Северном Кавказе // Центральная Азия и Кавказ. 2004. № 6 (36). C. 51-58. 
радикалами - фундаменталистами - с другой ${ }^{19}$. В 2011 г. в СКР было убито более 750 и ранено не менее 628 сотрудников правоохранительных органов, боевиков и мирных жителей. За первые 9 месяцев 2012 г. 574 человека были убиты и 422 ранены $^{20}$.

Салафитско-ваххабитские структуры тесно связаны с северокавказским бандподпольем. Несмотря на то, что многие сторонники салафитско-ваххабитских взглядов выступают в качестве пособников банддвижения: обеспечивают членов бандгрупп продуктами, одеждой, медикаментами и боеприпасами, предоставляют жилье и транспортные услуги, автор не отождествляет всех салафитов (ваххабитов) с террористами и экстремистами ${ }^{21}$. Необходимо учитывать, что северо-кавказское бандподполье отличается неоднородностью: наряду с религиозноэкстремистскими группировками (боевыми ячейками салафитсковаххабитских джамаатов) действуют криминальные группировки общеуголовной направленности, которые не имеют никакого отношения к исламу, но прикрываются кораническими аятами и хадисами Пророка для осуществления своей преступной деятельности (убийств, похищения людей, разбоя, вымогательств, бандитизма, незаконного изготовления оружия и др.)

Пособническую базу из приверженцев салафитско-ваххабитской идеологии можно условно разделить на «активных» пособников, оказывающих целенаправленное содействие членам бандформирований, и на «пассивных» пособников, оказывающих разовое содействие бандитам по дружеским и родственным мотивам в виде предоставления денежных средств, продуктов питания, медикаментов, автотранспорта, средств связи, ночлега.

19 В противодействии салафитам (ваххабитам) с 2000 г., по данным правоохранительных органов Чеченской Республики, погибли 9 тыс. человек и убиты более 60 глав местных администраций, представителей духовенства. Начиная с 1998 г. в Республике Дагестан было убито свыше 50 муфтиев, их заместителей и известных имамов, придерживавшихся традиционного для Северного Кавказа ислама. В 2012 г. были совершены теракты в отношении традиционных мусульманских богословов Республики Татарстан. См. Дадуев М., Нунуев С.-X. Этнический и религиозный экстремизм как угроза национальной безопасности в постсоветском пространстве (на материалах Северного Кавказа) // Россия и мусульманский мир: научно-информационный бюллетень / РАН ИНИОН. М., 2013. № 4 (250). С. 41-51; Силантьев Р.А. Чисто ваххабитские убийства: Радикальные исламисты уничтожают своих оппонентов по отработанной годами схеме // Независимая газета. Религии. 2012. 5 сентября; Яхьяев М.Я. Религиозно-политический экстремизм на Северном Кавказе: проблемы предупреждения / Материалы III Всероссийской научно-практической конференции «Концепция противодействия терроризму в Российской Федерации. Комплексный подход к формированию и функционированию системы противодействия распространению идеологии терроризма. М., РГУНГ, 2012. Т.1 С. 123.

20 Северный Кавказ: сложности интеграции. II. Исламский фактор, вооруженное подполье и борьба с ним. Доклад Международной кризисной группы. URL: http://www.polit.ru/article/2012/12/25/Islam_the_Insurgency_and_Counter-Insurgency/ (дата обращения: 04.01.2013).

21 Значительная часть салафитов (ваххабитов) не использует насильственные методы и не стремится к независимости от России. Реальную опасность представляет «жесткий», просаудовский вариант салафизма (ваххабизма), который используется для поощрения убийств и терроризма. Цит. по Хасан М. Источник террора. Идеология ваххабизма-салафизма. М., 2005. 
В свою очередь, активных пособников бандформирований также можно условно разделить на несколько групп:

- одобряющих радикальные идеи джихада, но не участвующих в нем;

- идеологов-агитаторов, способных вести теологические проповеди, участвовать в богословских дискуссиях и привлекать в салафитсковаххабитские общины новых сторонников;

- «боевиков-муджаидов», ведущих джихад, и «смертников».

Мотивированность участия и степень вовлеченности в террористическую деятельность бандподполья влияют на возможность применения профилактических мер воздействия в отношении той или иной категории пособников.

В отношении «боевиков-муджаидов» и «террористов-смертников», имеющих нигилистическое правосознание, профилактическая работа представляется неэффективной. При этом борьба с терроризмом и иными экстремистскими проявлениями на Северном Кавказе, в которой преобладает только «силовая» составляющая, имеет мало шансов на успех. Нейтрализация одних бандгрупп приводит к возникновению других, вчерашние пособники сами становятся активными участниками бандподполья.

Следует признать, что религиозный экстремизм и терроризм в Северокавказском регионе будут существовать до тех пор, пока руководство Российской Федерации не предпримет самые активные меры по устранению комплекса причин, их порождающих.

Проповедники идей «чистого» ислама умело используют протестные настроения общества, массовую пропаганду исламского образа жизни и шариатского правления. Салафитско-ваххабитские идеи рассматриваются населением как форма социального протеста и борьбы за свои права (востребованность идей социальной справедливости, равенства, братства, высокого морального облика мусульман, борьбы с коррумпированной государственной властью и преступностью).

Формирование и функционирование конституционных органов власти, которые в ряде случаев покровительствуют организованной преступности, наносят ущерб экономике, ущемляют конституционные права и свободы граждан, способствуют росту социальной напряженности, дискредитирует государственную власть и разочаровывает население в демократических ценностях.

Одной из причин радикализации можно считать незрелость молодых исламских лидеров, отсутствие у них достаточного жизненного и политического опыта, их неспособность идти наперекор эмоциям и максимализму части молодежной исламистской среды, неумение адекватно оценить существующие социально-политические реалии ${ }^{22}$.

${ }^{22}$ Макаров Д.В. Несостоявшееся возрождение умеренного исламизма в Дагестане. URL: http://www.islamrf.ru/news/umma/islam-world/2585 (дата обращения: 07.05.2013). 
Радикальные общины пополняются за счет молодых людей, которых туда толкают материальная и социальная неустроенность, безработица, невозможность продолжить образование. Принятие салафизма (ваххабизма) означает для них удовлетворение социальных потребностей (уважение окружающих, взаимопонимание, моральную и материальную поддержку, защиту $)^{23}$.

Определенное место в распространении на Северном Кавказе радикальных религиозно-экстремистских идей занимает иностранное вмешательство. Как отмечает М. Махкамов, «самоустранение государства от решения вопросов, связанных с исламским фактором, способствовало бесконтрольному вмешательству Саудовской Аравии, Ливии, Сирии, Турции, ОАЭ, Пакистана в дела мусульманского сообщества России» ${ }^{24}$.

Проводниками идей «чистого» ислама наряду с зарубежными миссионерами стали мусульманские священнослужители, получившие образование за рубежом. Именно из них начинает оформляться антироссийская элита, агрессивная по отношению к истории, политике, культуре России. Для нее Россия - исторический «враг-поработитель», поэтому они призывают к «священной» войне против русского присутствия на Кавказе.

Не последнюю роль в активном распространении салафитсковаххабитской идеологии играет пассивная роль «официального» ислама (ДУМ и подчиненных им религиозных образований). Как отмечает В.А Смирнов, одной из причин салафитско-ваххабитской экспансии является более «слабая богословская подготовка ортодоксального мусульманского духовенства в сравнении с салафитско-ваххабитскими идеологами, получающими идейную и политическую подготовку в известных центрах мусульманского Востока» ${ }^{25}$.

По мнению специалистов, за безобидным на первый взгляд внедрением идей салафизма (ваххабизма) в массовое сознание непременно следует этап создания вооруженных джамаатов, а затем выдвигаются требования смены конституционной власти ${ }^{26}$.

Несмотря на предпринимаемые правоохранительными органами усилия (уничтожение бандглаварей, амнистирование, профилактические

${ }^{23}$ Такушинов Ш.Н. Исследование причин религиозного экстремизма в молодежной среде в Карачаево-Черкесской Республике / Материалы III Всероссийской научнопрактической конференции «Концепция противодействия терроризму в Российской Федерации. Комплексный подход к формированию и функционированию системы противодействия распространению идеологии терроризма. М., РГУНГ, 2012. Т.2 С. 138.

24 Цит. по Дадуев М., Нунуев С.-Х. Этнический и религиозный экстремизм как угроза национальной безопасности в постсоветском пространстве (на материалах Северного Кавказа) // Россия и мусульманский мир: научно-информационный бюллетень / РАН ИНИОН. М., 2013. № 4 (250). С. 41-51.

${ }_{25}$ Аналитический вестник Совета Федерации Федерального Собрания Российской Федерации. 2005. № 11 (63). С. 77. См. также Мантаев А.А. «Ваххабизм» и политическая ситуация в Дагестане. Дис. ... канд. полит. наук. М., 2002. С. 94.

26 Аналитический вестник Совета Федерации Федерального Собрания Российской Федерации. 2005. № 11 (63). С. 75. 
меры), обстановка по линии противодействия религиозному экстремизму на территории Северного Кавказа остается напряженной.

Носителями экстремистской идеологии по-прежнему выступают радикальные салафитско-ваххабитские структуры, которые адаптируют свою террористическую и иную экстремистскую деятельность к динамике общественно-политической и внутриконфессиональной обстановки, тактике действий правоохранительных органов СКФО.

В качестве актуальных угрозообразующих тенденций в салафитсковаххабитской среде Северо-кавказского региона можно выделить следующие:

- ориентация идеологов «чистого» ислама на Интернет-пространство и активное привлечение молодежи ${ }^{27}$;

- массовое распространение радикальных салафитско-ваххабитских взглядов в учебных заведениях и мечетях;

- организация салафитами (ваххабитами) «мусульманских» детских и юношеских лагерей, где под видом военно-спортивной подготовки детям преподается нетрадиционная трактовка ислама и прививаются навыки ведения боевых действий ${ }^{28}$;

- создание боевых групп для силовой поддержки салафитских (ваххабитских) общин;

- создание общественных организаций и привлечение внимания правозащитных структур для легитимации своей деятельности.

Идейно-политическая направленность данных тенденций свидетельствует об использовании радикальными салафитами (ваххабитами) псевдоисламского прикрытия для осуществления террористической и иной экстремистской деятельности в ущерб конституционному строю Российской Федерации.

Таким образом, проведенный анализ генезиса и сущности салафитсковаххабитских религиозных взглядов на территории Северного Кавказа, влияния салафитско-ваххабитского фактора на общественно-политическую жизнь региона позволяет сделать следующие основные выводы:

1. Радикальные салафитско-ваххабитские псевдоисламские идеи, распространяемые в настоящее время на территории СКР, имеют экстремистскую природу. В общественно-политической сфере фундаменталисты призывают к замене светских («безбожных», «кафирских») органов публичной власти властью Аллаха и созданию на пути джихада справедливого государства с шариатской формой правления. При этом

27 Салафитско-ваххабитские информационные ресурсы (Kavkaz-Center.com, Kavkaz.org.uk, Camagat.com, Guraba.info, VDagestan.com, Hunafa.com, Islamdin.biz, Imamtv.com, Nuruddin.info, Nohchipress.info, Daavat.me (включая их «зеркала»)) помимо пропаганды (даваата) салафизма, материалов о лидерах джихада произвольно и манипулятивно толкуют Коран и хадисы, интерпретируют джихад как войну с инаковерующими, обвиняют представителей традиционного для СКР тариката в неверии (куфре) и многобожии (шикре). Среди участников бандформирований СКР наибольшей популярностью пользуются видеолекции таких идеологов радикального ислама, как Саид Бурятский, Анзор Астемиров, Хаттаб, Мухаммед Багаутдин, Айрат Вахитов.

28 Такие лагеря выявлены в Республике Дагестан и Республике Башкортостан. 
отвергаются федерализм, светский характер государства, верховенство Конституции Российской Федерации, ценность институтов народного представительства и конституционно-правовых процедур их формирования.

Носители салафитско-ваххабитских идей имеют нигилистическое правосознание, подвергают сомнению демократический путь разрешения противоречий в обществе и необходимость участия в политической жизни.

2. В мусульманских республиках Северного Кавказа объективно сложился широкий спектр факторов, способствующих активному распространению салафитско-ваххабитской идеологии. Проповедники идей «чистого» ислама умело используют протестные настроения общества, массовую пропаганду исламского образа жизни и шариатского правления. Салафитско-ваххабитские идеи рассматриваются населением как форма социального протеста и борьбы за свои права (востребованность идей социальной справедливости, равенства, братства, высокого морального облика мусульман, борьбы с коррумпированной государственной властью и преступностью).

3. В салафитско-ваххабитской среде СКР сформировался ряд угрозообразующих тенденций, усиление которых неизбежно ведет к активизации террористической и иной экстремистской деятельности бандподполья, направленной на подрыв конституционного строя Российской Федерации. Нейтрализация указанных тенденций и позитивное воздействие на динамику общественно-политической жизни на территории Северного Кавказа возможны на основе продуманной национальной политики, содействия внутри- и межконфессиональному диалогу ${ }^{29}$, укрепления конституционных институтов власти, восстановления доверия населения к правоохранительным органам, адаптации бывших участников бандподполья и реализации в религиозных и светских учебных заведениях образовательных программ, направленных на противодействие религиозному радикализму и экстремизму.

29 Так, в Совет улемов Духовного управления КЧР входят «умеренные» салафитские лидеры. 29 апреля 2012 г. в г. Махачкале Духовным управлением РД и Ассоциацией ученых «Ахлю-Сунна» было решено создать комитет для разрешения споров, в котором на паритетных началах представлены ученые-суфии и салафиты. 